\title{
'The Best Crop the Land Will Ever Grow': W.F. Massey through the Lens of Environmental History
}

\section{MICHAEL ROCHE}

Shortly after entering Parliament in 1894 as MP for Waitemata, Bill Massey repeatedly pressed John McKenzie, the formidable Minister of Lands in the Liberal government, over claims of illegal killing, skinning and the sale of native birds from Little Barrier Island, which had been acquired that same year as a flora and fauna reserve. Massey even quoted in translation a letter from Kiri and Tenetahi naming the perpetrator, before describing the species in question, the stitchback, as 'the rarest and most beautiful and valuable of native birds, as members could see if they look at Sir Walter Buller's book on the subject'. In the 30 year parliamentary career that followed, Massey was generally more circumspect about applauding rarity and beauty in nature. In part, this was because, as Barry Gustafson has written, Massey 'saw farmers as the developers of the countryside, the base of the economy and the personification of the young nation's pioneering spirit'. ${ }^{2}$ Gustafson noted that this attitude brought Massey and the Reform Party into conflict with sectional interests, particularly the unions and the Labour Party. This provides clues as to the perspective from which Massey viewed nature, natural resources and what he and many others of the time termed 'preservation' - which today we might call 'conservation' and 'environmental management'.

This paper pulls together Massey's views about natural resources and conservation as expressed across his political career. It adds to the small body of biographical work that explores the conservationist impulse in late nineteenth and early twentieth century New Zealand. In this respect, Galbreath's book on naturalist Sir Walter Buller is something of a pioneering study, one that is especially poignant with respect to Buller's ambiguous and contradictory role as destroyer and protector of rare birds. ${ }^{3}$ Galbreath's subsequent dual biography of father and son George and Allan Thompson further adds to the understanding of science and politics in early twentieth century New Zealand. ${ }^{4}$ This work is pertinent to the present paper in that G.M. Thomson was a newly elected member of Massey's Reform government in 1912. Sir James Wilson, who was a behind-the-scenes influence on Massey as far as forestry was concerned, was the subject of an earlier biography by 
Wild. ${ }^{5}$ This paper, by focussing on a specific individual, also complements the broader themes developed in Pawson and Brooking's Environmental Histories of New Zealand ${ }^{6}$ and more specialised treatment of topics such as weeds by Clayton. ${ }^{7}$

As a pragmatic political conservative, Massey provides a contrast to the more progressive and radical political thinkers on whom histories of conservation and environmentalism have often focused. ${ }^{8}$ Massey's opinions arguably mirror those of the mainstream population, in contrast to the early conservationists such as Liberal MP Harry Ell, whose well-documented views may strike a chord with early twenty-first century environmentalists, but who was, relatively speaking, something of an extremist in the early twentieth century. ${ }^{9}$ In addition, Massey was Prime Minister at the time when, after false starts in the 1870 s and 1880 s, decisive efforts were made to place state forestry on a professional footing in New Zealand. Forestry has often had a central place in national accounts of environmental management. ${ }^{10}$ Forestry and farming were typically competing forms of land use, and the way in which Massey accommodated the two is of interest. Massey's political career, both in opposition and government, situated him in the midst of some important debates about the use and preservation of natural resources from the 1890 s to 1920 s, a period that coincided with tremendous changes in the 'natural' environment in New Zealand. This particularly related to forests but also included the spread of pests and weeds across the farm landscape. ${ }^{11}$

Until 1912, Massey was in opposition, and from then until his death in 1925 he was Prime Minister, still the second longest term on record in New Zealand. This paper does not set out to rediscover Massey as some forgotten leader of the conservation movement in New Zealand, but seeks to explore his understanding of what today would be labelled 'environmental issues'. To do so, it is necessary to place him against the backdrop of the Liberal Party, in government from 1891 to 1912, and its radical land policies. The Liberal Party's enduring political legacy includes votes for women and old age pensions. As David Hamer observes, however, 'it was the land question that mattered to the Liberals'. ${ }^{12}$ This has been explored in depth in Tom Brooking's biography of John McKenzie (1839-1901), the Liberal Minister of Lands from 1891 to 1900, in relation to the 'bursting up' of the Great Estates through the purchase of large amounts of Maori land in the North Island in order to provide the farmland for settlers. ${ }^{13}$ Massey emerged onto the political scene as a small farmer from south Auckland who articulated farmers' growing frustration with the Liberal government's land policies. While Massey also supported continued land development and an expansion of the rural economy, he believed that this should be based on freehold farms. Freehold versus leasehold was the visible tip of the conflict between 
the progressive interventionism of the Liberals and the individualistic conservative position of what became the Reform Party under Massey. Thus the Liberal and Reform parties approached preservation and conservation from somewhat different political directions.

Specifically, this paper concentrates on Massey's attitudes to the preservation of natural resources and nature as the inverse of (rural) economic development. It explores his criticisms of the balance struck between the two by the Liberal government and his later justification of the position arrived at by the Reform Party while in government. Massey's political career played out in the context of large-scale and rapid environmental change in New Zealand. Closer land settlement reduced the forest cover of the North Island, and as the indigenous flora and fauna were threatened, so efforts were made to preserve selected areas for both utilitarian and aesthetic purposes. Various institutional arrangements were introduced while Massey was in opposition, and it is interesting to see how he criticised and/or reconciled these initiatives with his ideas about freehold land tenure and a reduction of state control. As Prime Minister, Massey was to preside over the creation of the State Forest Service in 1920, a cornerstone for state-led 'wise use' conservation in New Zealand as elsewhere.

One proxy measure for environmental change in New Zealand is the reduction of forest area since 1840. The New Zealand State Forest Service in 1930 suggested that this had declined by $45 \%$ from 27.6 million acres in 1847 to 12.5 million acres in $1923 .{ }^{14}$ Some $1,516,452$ acres of forest were cleared from Crown lands by selectors from 1895 to $1912 .{ }^{15}$ The scale and rate of change is significant, even though less forest had been cleared by 1923 than the Forest Service figures indicate. ${ }^{16}$ Associated with this was the draining of swamps; the extinction of various indigenous species, particularly birds (disruptive of traditional Maori food sources); the introduction, both deliberate and accidental, of an array of familiar European species as well as those from other lands; and the conversion of New Zealand to a grassland economy so complete that of 670,000 ha of freshwater wetlands in 1840 , only 100,000 ha now remain. ${ }^{17}$ Forest clearance probably peaked around the 1890s-1900s, while the 1900-1920s saw the highest rate of land drainage. Such transformations coincided with, and helped give impetus to, efforts to protect remnant areas of indigenous fauna through the creation of island sanctuaries, national parks and scenic reserves. In addition, deforestation triggered fears about a future 'timber famine' and the prospect of New Zealand becoming dependent on imported wood.

\section{Expanding the margins of settlement}

Massey entered Parliament in 1894 aged 38, after an active political apprenticeship in local and farmer organisations. ${ }^{18}$ His political philosophy 
was well ingrained by the time he became an MP. It provides the key to understanding his attitudes towards natural resources and what he tended to term 'preservation'. Central to Massey's position on preservation was his support for freehold land tenure, and associated with this was a reluctance to admit much of a role for the state. This combined with a philosophical reaction against compulsion and a pragmatic objection to unnecessary costs and inefficiencies. However, he was, under some circumstances, prepared to accept local regulation if entered into voluntarily. These sorts of attitudes, shared by his small-farmer constituency, were repeatedly displayed when Massey spoke on matters pertaining to the environment and natural resources in Parliament.

Massey pushed for economic development but opposed compulsory government land purchase and subdivision for closer settlement. He believed there was sufficient unoccupied Crown and Maori land for prospective settlers. This preference for expanding the margins of settlement also led him to push for revocation of forest reserves, to support government swamp drainage, as well as to advocate the acquisition of Maori land. He shared the 'developmentalist' goals of the Liberals but differed over the means of achieving them.

Some of these views were evident when he spoke on the Lands for Settlement Bill in 1897, stating that 'I think freehold should be sacred - that it should not be interfered with in any case where we can possibly avoid it'. He followed this by claiming that:

it would be much better to do more in the way of settling on Crown and Native lands instead of running the country into debt for the purchase of privately owned lands in the manner proposed in the Bill. We have even now in the North Island large areas of Crown and Native land lying unoccupied. ${ }^{19}$

Prior to and after Massey entered the House there had been a small number of proposals to remove forest reserve status from areas of Crown land and to release them for settlement (Table 1). Being generally supportive of such moves by the Liberals, Massey did not speak frequently. Sometimes when he later did, he entered into a testy exchange with PM Sir Joseph Ward over parliamentary etiquette, rather than debating the actual opening of forest land for settlement. ${ }^{20}$

Massey acknowledged land settlement deficiencies, though he did not blame the small settler. He instead focussed attention on what he believed were legislative shortcomings:

By the operation of our idiotic land laws millions of pounds worth of really good timber was destroyed because we made it a condition that settlers must do a certain amount of improvement which of course, 
included bush felling, otherwise their sections would be forfeited ... we were not doing as much as we ought to in the way of preserving the timber that was left, or of encouraging settlers to plant more timber. As to what had been done in the past ten years he believed that succeeding generations would rise up and curse us for our stupidity. The best crop the land would ever grow had been ruthlessly destroyed and for no good purpose. ${ }^{21}$

This statement is interesting on a number of counts. It reveals Massey's characteristic wariness of the capacity of the state to perform better than individuals, and it shows he did recognise that there were limits to settlement, beyond which timber was the 'best crop'. His reference to 'preserving the timber' was meant in the sense of setting aside forest land for future use, rather than for its inalienable protection. By implication, however, he viewed farming as superior to forestry as a long-term land use. Massey accepted contemporary ideas about the impossibility of saving the indigenous forest, and favoured tree planting as a solution to future timber supply problems. The 'best crop' view implied that the indigenous forests should be harvested more effectively and less wastefully. It was widely accepted in official circles by the early 1900s that supplies would be exhausted by the mid twentieth century. ${ }^{22}$ Massey's position was consistent with the understanding that remaining supplies should be eked out. But, as later events were to reveal, Massey had no real appreciation of the professional foresters' goal of sustained-yield management.

Massey often returned to well-rehearsed themes of the power of the state and the unintended and adverse economic consequences that stemmed from this. In the 1899 debate on the Kauri Gum Bill, which was intended to define gum-digging areas and limit the issue of licenses to the British, British naturalised citizens and Maori, he proclaimed:

We are placing an immense power in the hands of the Government of the day by empowering them to set aside large areas of country as kauri-gum reserves and thereby exclude the Austrians there from. If you exclude the Austrians from the country north of Auckland, the kauri gum industry - one of the most important industries - will be seriously affected and the Austrians ${ }^{23}$ driven from the gumlands, will be brought into competition with our own people in other parts of the country. ${ }^{24}$

In later years, Massey made further references to gum lands and, as the gum was exhausted, advocated turning these areas into farm lands by 'attaching... [the gum diggers] to the soil' via government settlement schemes on 100 to 150 acre farms. ${ }^{25}$ The 'industrious man' on the gum fields, as elsewhere, who showed the signs of wanting to become 'a permanent settler should be given the opportunity to do so, including naturalisation', he said. ${ }^{26}$ 
Massey also supported the countrywide expansion of settlement onto swamplands. In 1904, he discussed a favourite whipping horse, government acquisition of estates, in the context of the draining of the Piako swamp. He claimed that it "would be better to spend some of the money now being paid for the acquisition of large estates on this land and make it available for settlement than to go on as present'. ${ }^{27}$ He spoke in some considerable detail about the arduous work of digging drains and of the time taken before the land could be burned off and grass established. And it would be "probably two or three years after that before it is sufficiently consolidated and carrying heavy stock'. ${ }^{28}$ On a subsequent occasion in 1911, he was particularly critical of government efforts to amend the Hauraki Plains Act. His interest was the economic welfare of the settlers who, he believed, were being penalised by rates and continued government involvement in the scheme. He considered that it would be better for the government to drain the land and then to pass it over to a locally elected drainage board to maintain it. ${ }^{29}$ His views on the importance of swamp lands strengthened, so that by 1924 he claimed that 'some of our best land today is drained swamp land. Most of our butter comes from land that was once swamp land'. Of Southland and the Seaward moss area he observed, matter-of-factly: 'I do not see why that swamp should not be turned into good land. It is a question of fall'. ${ }^{30}$

\section{The 'duty of government' and environmental management for the farmers}

While in opposition, Massey frequently spoke in the House about the 'duty of government', particularly as it related to small farmers. He was prepared to admit the state had a role in protecting and improving the productive landscape of the farm. By the 1890s, a number of introduced insect pests and weeds were causing difficulties for farmers. Massey inquired about the possible introduction of a natural predator - the Kohlmeise, or Codlin Moth-eating bird, from Germany - but was told that the Department of Agriculture had decided it would be unsuccessful and instead favoured chemicals and spray pumps. ${ }^{31}$ Over the next several years, he entered more fully into discussions about the problems of weeds such as blackberry and Californian thistle. Given that Massey applauded the individual judgement and efforts of settlers, supporting a noxious weeds bill posed some problems. He explained himself as follows:

I am reluctantly compelled to admit that something in the way of a Noxious Weeds Act is necessary and I have been led to this way of thinking by having noticed the rapid growth of such plants as blackberry and sweetbriar on the unoccupied lands of the colony. ${ }^{32}$

It was their presence on unoccupied Crown land that was the key to his stance, since no individuals could be held directly responsible for the spread 
of weeds from these lands to adjacent farms. He did, however, withhold full support for the noxious weeds bill because he considered that it attempted to control too many types of weeds when it ought to have focussed on the two or three major threats. Not surprisingly, he also believed it ought to be 'permissive' and brought into effect by a poll of local rate payers. Returning to a persistent theme he asserted: 'There is no class in the community more important of unnecessary interference or who admit to a freer hand in connection with their business than the country settlers'. ${ }^{33}$ Such control as was required ought to be put into effect by local bodies that were the 'best judge' of what was right for their districts.

This first attempt to pass noxious weeds legislation foundered, as Massey anticipated, because it proposed to control too many weed species. ${ }^{34}$ Subsequently, a Californian Thistle Bill was introduced in an attempt to control what, in Canterbury at least, was a major problem. Massey chose to point to the increased costs that would be required for the government to clear public reserves as envisaged by the bill. He recognised the seriousness of the thistle problem and its potential economic impact. If not solved, 'farmers in other parts of the colony would be very careful indeed about using Canterbury grass-seed. They might be sowing not only grass-seed but Californian thistles'. ${ }^{35}$ He repeated his position on local body rather than central government control of the implementation. When a further Noxious Weeds Bill was introduced in 1900, he was generally supportive. But he did highlight where he thought it unduly interfered with the rights of land holders, and he also intimated that it would cost too much. The first point related to a requirement for settlers to cut hedges annually. Why should they, Massey asked, 'unless they are shown to be a nuisance to their neighbours'. His second worry stemmed from clauses that provided for the clearing of weeds from public reserves and Maori Land not on individual title. He remarked, with a rare display of humour, that 'It would cost as much to give effect to these two clauses as to build the North Island Trunk line'. ${ }^{36}$ In 1905, it was officially estimated that the annual cost of controlling noxious weeds on Maori land, Crown land and unoccupied reserves would total $£ 213,645$, of which $£ 131,000$, or $61 \%$, was concentrated in the Auckland Land District. ${ }^{37}$

Massey continued to speak on noxious weeds for the next decade, enquiring, for instance, as to whether the Department of Agriculture had tested the latest weed eradicators. ${ }^{38}$ Around 1907-1910, his focus shifted to the way in which the Noxious Weeds Act was being interpreted. Massey was quick to defend the small farmer against the powers of the Noxious Weed Inspectors and the rulings of magistrates who were fining land owners for failure to clear blackberry - Massey argued that annual cutting prior to flowering was sufficient to halt its spread. ${ }^{39} \mathrm{He}$ did acknowledge the 
seriousness of the problem for farming, and accepted that some legislation was necessary to 'prevent the spreading of noxious weeds by the carelessness of a small portion of the settlers'.$^{40}$ The real issue as he saw it, however, was twofold: the continued problem of weeds spreading unchecked on Crown and Maori land, thence to settlers land; and the impact of weeds on prices for Crown land. Weed infestation, in his view, reduced the value from between $15 \mathrm{~s}$ and $£ 1$ per acre to $5 \mathrm{~s}$, and it would cost a settler $£ 2$ to $£ 3$ per acre to occupy. For Massey, the most effective means of weed control came through 'settling the land'. He also claimed 'blackberry was simply running riot' on the 'best lands of the North Island - the semi drained swamplands'. By this time, he was also prepared to admit other solutions, though this took the form of an admonishment of the government for "not doing enough in the application of scientific methods to the eradication of weeds' ${ }^{41}$ In government, he took a softer tack, claiming that 'a drastic enforcement of the Act would drive many people off their holdings'.$^{42}$

Orchard pests were back on the legislative calendar in 1903, and Massey supported the object of the bill before Parliament. Prevention of the introduction of pests and disease sat comfortably with his idea of the state's function. But typically he criticised the clause that made growers responsible for controlling pests and disease on their own orchards, offering the less than convincing argument that the bill did not specify the exact steps to take to achieve this end. He continued to press for the introduction of natural enemies of Codlin Moth, and quoted at length in support from the report of the Western Australia Agriculture Department entomologist. ${ }^{43}$

The danger of anthrax posed by diseased bones imported from India to be ground into fertiliser was another area where Massey laid out his views on the responsibility of government. 'The duty of the government was to take the necessary steps to stamp out the disease and prevent its reintroduction in the future', he affirmed. 'It was the duty of the Government to see that farmers get these supplies at reasonable rates and on the other hand it was their duty to see that no disease was imported in the bones that were to be converted into manure ${ }^{44}$ Here, Massey was prescribing a role for the state in border control, but not in regulating the economy in terms of the actual manufacturing of the fertiliser.

\section{Lands unsuitable for settlement}

Massey accepted that forest preservation for scenery or protection purposes was 'acceptable in principle' on lands unsuited for settlement. While conceding the principle, he was silent in the House during the passage of bills to create four national parks from 1894 to $1905 .{ }^{45}$ Perhaps the concept of a national park was too novel - Tongariro, in 1894, was only the third such park in the world - or maybe he felt no particular need to contribute 
as neither his electorate nor constituency was directly impacted, and he had other pressing political commitments and responsibilities as he gradually assumed leadership of the opposition. As Minister of Lands in 1913, however, he did forward requests to extend Tongariro National Park to include forest areas. ${ }^{46}$ When the Tongariro National Park Act was amended in 1922, Massey only very briefly and insignificantly interjected in the discussion about the spread of heather. ${ }^{47}$

It was usual for speakers seeking preservation of scenic areas in New Zealand to simultaneously praise their beauty and emphasise the unsuitability of the proposed parks for settlement. In this regard, the Scenery Preservation Bill of 1903 potentially presented more of a challenge. As well as gazetting Crown land as scenic reserves, it was intended to secure the purchase and reservation of many small areas of freehold and Maori land across the country, some of which fell within, rather than clearly outside, the agricultural margins.

Seddon, after prompting by Christchurch Liberal MP Harry Ell, introduced the Scenery Preservation Bill in 1903. He set up a commission to identify sites on land of all tenures in order, once and for all, to preserve in perpetuity scenic and historic places throughout the country as scenic reserves. ${ }^{48}$ Massey, although uncharacteristically caught unprepared, agreed that the bill 'served a commendable purpose'. He did, however, place a greater weight on historic rather than scenic features, making reference to Maori and Pakeha battle sites and those from earlier conflicts between Maori. While acknowledging these were of 'comparatively little interest to the present generation', he suggested they would be 'looked on with more and more importance by the people who will follow us' ${ }^{49}$ True to form, he expressed concern about the excessive sum of $£ 100,000$ set aside to complete the tasks outlined under the bill, and unsuccessfully attempted to have this reconsidered.

After the legislation was in place, Massey did identify some spots along the route of the main trunk railway line that he considered worthy of acquisition as scenic reserves. In 1909, he inquired about progress on efforts to purchase the bush at Day's Bay across the harbour from Wellington city. In 1910, he even drew the minister's attention to 'a beautiful piece of bush' along the road near Ngaruawahia that was under threat from the construction of a tram-line for a coal mine. ${ }^{50}$

On taking office as Prime Minister in 1912, Massey assumed a number of other portfolios, including those of Agriculture and Lands. He also became Commissioner of State Forests (the term used instead of Minister) and Minister in Charge of Scenery Preservation. In the following years, he dutifully, if not especially proactively, referred on to the Scenery Preservation Board requests from parliamentary colleagues to have areas gazetted as 
scenic reserves. In 1915, however, responding to requests from miners, he was quick to bring in an amendment to enable gold prospecting on scenic reserves, reiterating the point that scenery preservation ranked behind other land uses. The amendment was partially offset by the introduction of more stringent regulations for the protection of indigenous birds in scenic reserves. One of Massey's last parliamentary utterances was to agree to seek the preservation of an area of scenic bush in the Hutt Valley. ${ }^{51}$

Massey relinquished the portfolio of Lands to David Guthrie in late 1918, while Sir Francis Bell took over as Commissioner of State Forests and Minister in Charge of Scenery Preservation. Unlike Massey, Bell immediately saw the potential conflicts between the two portfolios, and in 1919, Guthrie assumed responsibility for the latter. ${ }^{52}$

\section{Forests and forestry}

In opposition, and early on in government (as Minister of Lands), Massey moved to have the forest reserve status of a number of areas removed to allow the land to be opened for settlement. Although, in its first years, the Reform government introduced more motions to revoke State forest than did the Liberals, the number of petitions to resume state forest lands soon returned to earlier levels of one or two per year (Table 1). When further state forest reservations are considered, the total area of state forest declined by 50,000 acres from 1912 to 1915 and then rose by 30,000 acres by 1918 (Table 2). Massey's favouring of land settlement was thus only to a limited extent secured at the expense of the Crown forest estate.

After taking office and assuming the Lands portfolio, it fell to Massey to introduce motions to withdraw state forest status. In 1913, for example, he moved that forest reserves status be lifted from 12,894 acres of land near Martinborough which had been set aside under the Forest Act 1908. He explained that the action was justified on the grounds that the land, valued at $£ 1 / 5$ per acre, was suitable for grazing and because of fire damage to some two-thirds of the area. The remaining forest was considered to be 'in imminent danger of being swept by fire when the settlers clear their holdings down the lower spurs'. ${ }^{53}$ While newly elected fellow Reform MP G.M. Thomson urged, as a general principle, that forest lands should not too easily be given up, Massey, on balance, was of the view that 'it would be more in the interests of the country if the land was settled in the ordinary way than set aside for the purposes suggested. They had to remember that ordinary Crown Land was becoming scarce in this country'. ${ }^{54}$ Liberal MP Harry Ell launched onto the attack, saying that 'He did not want to be egotistical or to imply that the House was getting careless, but it did seem to him that they were not careful enough with their inquiries made with regard to the position'. A city MP, he baldly stated that 'the average 
settler was very largely a speculator and this disposition for speculation was responsible for a great deal of the waste of valuable timber that was going on'. ${ }^{55}$ Massey did not respond on this occasion, having, when in opposition, made similar claims. ${ }^{56}$

As early as 1896, the report of the Timber Conference gave weight to the idea that New Zealand was facing a timber famine and that the way forward was for the state to establish exotic forest plantations. The first moves in this direction were made at Whakarewarewa in 1897. Detailed reports on the timber industry were carried out by the Department of Lands in 1905 and 1907. In 1908, the eminent botanist-ecologist Leonard Cockayne, reporting on Waipoua kauri forest, argued for its preservation on scientific as well as scenic grounds. ${ }^{57}$ Massey had earlier spoken out on forests in the supply debate of 1906, beginning by questioning why the vote was under-spent by $£ 8000$. He then proceeded in a manner that showed the extent, and the limits, of his appreciation of the problem:

The destruction of our forests was going on so rapidly throughout the colony that very soon there would be little left and very little comparatively had been done to replace the forests destroyed. Something must be done to encourage the settlers to do a great deal more replanting than in the past. ${ }^{58}$

Continuing, he identified Central Otago, North Auckland and 'the plains of Rotorua' as suitable areas for tree planting. Massey thus recognised the possibility of a timber famine, but he saw a solution only in the planting of more trees. Consistent with his views of the state, he appeared to see this taking place largely on private lands.

As Prime Minister in 1912, Massey, responding to a question in the House, suggested that 'a general scheme of afforestation for the needs of the Dominion ensuring private as well as Crown Lands is in the course of preparation'. ${ }^{59} \mathrm{He}$ gave an almost identical response to another question from Ell shortly afterwards. Before Massey had the opportunity to outline any 'afforestation scheme', he was asked by G.M. Thomson about plans for the appointment of a forester to manage the state forests. ${ }^{60}$ Massey now saw the value of appointing a commission to investigate the problem, for, as he explained, 'he had not the time to go into this matter personally'. ${ }^{61}$ But at the same time, his suggestion that the commission would consist of a 'couple of practical men to go into the whole matter' implied a limited perspective which would probably have concerned Thomson. ${ }^{62}$

A Royal Commission on Forestry was set up in 1913. Its terms of reference included reporting on:

1. Which of the existing forest land ought to be permanently retained for flood protection, soil and water conservation, and scenery. 
2. What other forests were suitable for settlement and sawmilling and whether they should be opened at once or reserved for future use.

3. The best method for dealing with indigenous forest.

4. Whether kahikatea ought to be exported. ${ }^{63}$

5 . The likely future demand for timber.

6. The types of timber that would be required.

7. The extent to which demand would be met from state tree plantations.

The commission comprised of Thomas Adams, Samuel Clarke, Frank Lethbridge, Charles Murdoch, Dr Leonard Cockayne, the botanist, and it was chaired by Henry Haszard, the Commissioner of Crown Lands for Westland. It was largely made up of Massey's 'practical men': Adams was a noted farmer and tree planter; Clarke, a builder, had earlier been a member of the 1909 Timber Commission; Lethbridge was a farmer; and Murdoch was a woodware manufacturer. Haszard had some interest in the growth rates of indigenous trees, but only Cockayne had any scientific background, and this was in botany and ecology, not forestry.

Massey, perhaps surprisingly, addressed the commissioners. He concerned himself with asserting the claims of land settlement:

Members of the Commission who happen to be residents in the country will agree with me that in quite a number of places so-called scenery \& forest reserves have been set apart which are utterly useless \& unsuitable for their purpose. Settlers have complained to me over \& over again that some of these places have simply become breeding-places for noxious weeds, \& very often noxious animals in addition.

He then restored some balance to the situation by referring to representations for the reservation of scenic areas alongside the Mokau River. The fundamental divide was clear enough to Massey:

I believe that something should be done to preserve many spots that are particularly suitable for scenery purpose, without interfering with the land that is suitable for settlement, but is not fit for the other purpose. ${ }^{64}$

It is noteworthy that Massey was largely speaking here about scenery preservation rather than forestry. He then spent some time talking about Waipoua kauri forest, and expressed sympathy for those arguing for its protection, while observing 'I have not sufficient knowledge of the case to decide whether or not that the forest be preserved'. He did, however, note that nearby there was another area of kauri forest (presumably Trounson's 
bush) that he strongly believed should be preserved. ${ }^{65}$ In the remainder of his address, he traversed the other terms of reference, noting the divisions of opinion that existed over the management of indigenous forests and the scale of tree planting required to meet future demands. He also expressed the opinion that the commission would not need to report its evidence and that its work would be quickly completed. This comment signals his practical problem-solving approach to the forests question. Massey subsequently forwarded a list of six forest reserves and six gum reserves, which included an area of swamp in Maori ownership, that he believed ought to be released for settlement. ${ }^{66}$

The commission received 88 witnesses before presenting a written report complete with 178 pages of evidence. Its recommendations included reserving 1.69 million acres for climatic and scenic purposes, releasing 45,470 acres of climatic reserve for sawmilling and settlement, classifying forests in terms of their suitability for sawmilling or settlement, sanctioning the continued export of scarce kahikatea, and increasing the state afforestation programme to 7500 acres per annum to meet excess timber demand predicted for the years up to 1948. The commission also recommended that 200 acres of Waipoua forest be set aside as a 'national kauri park', with the remainder milled and the land thrown open to settlement.

The report was rather inadequately discussed in Parliament. In parallel, however, there was an exchange about Waipoua kauri forest. Gordon Coates, MP for Kaipara, asked Massey if it was to be felled for timber and then sold off for settlement. In reply, he was told that Cockayne's 1908 report had drawn attention to the forest's 'remarkable values' and that the government did not intend to 'permit the destruction of this unique asset'. ${ }^{67}$ Massey continued, probably basing his comments on departmental notes by Edward Phillips Turner, latterly secretary to the Forestry Commission and previously Inspector of Scenic Reserves, that the government was following a similar line to those of 'the United States, Canada, Germany \&c. who preserve such national parks as Yellowstone, Yosemite Valley \&c. for the benefit of posterity as well as the present generations'. But in the very next sentence he backed off, stating: 'there is however (at Waipoua) a very serious danger from fire which cannot be overlooked and as settlement increased, the government realized this danger became greater', ${ }^{6} 8$

By 1914, in addition to G.M. Thomson, a number of individuals supported the idea of having an independent forest department staffed by professionally trained foresters. Supporters included Phillips Turner, now forestry officer for the Lands Department, the Rev J.H. Simmons, an expert on Eucalypts, and Sir James Wilson, who overlapped for three years with Massey early on in his parliamentary career and was a long-time president of the Farmers Union (1900-1920), as well as being the inaugural president of the Board of 
Agriculture. ${ }^{69}$ The Royal Commission on Forestry did not satisfy some of the forestry advocates, however. They maintained their pressure, with Wilson writing to Massey in 1914 through the Board of Agriculture and suggesting that the eminent colonial forester David Hutchins, then in Australia, be invited to report on New Zealand's forests. This was intended to provide the final impetus for the establishment of a forest department separate from the Lands Department.

Wilson's appeal was successful, and Hutchins was asked to produce a report. Hutchins interpreted his brief rather more widely than the Under Secretary of Lands, who issued the invitation, intended. He focussed his attention on the indigenous forests, partly to offset what he saw as one of a fundamental weakness in the 1913 Royal Commission ${ }^{70}$ report: its favouring of exotic afforestation at the expense of indigenous forest management. Hutchins involved himself with Wilson in the formation of the New Zealand Forestry League in 1916. He made many statements about the need for scientific forestry throughout the country, wrote a number of articles on this theme and eventually produced two reports, entitled Waipoua Kauri Forest and Forest Management in New Zealand, the second part of which was never published..$^{71}$

Hutchins attempted to persuade the pro-forestry lobby, with the exception of Phillips Turner who already shared the view, that they should think of forestry as more than exotic plantations. In New Zealand, he argued, forestry fundamentally ought to involve the management of indigenous forest on sustained-yield principles. Hutchins reiterated this point to Massey on several occasions. In 1917, he wrote: 'May I mention again that the urgent need now is not re-afforestation (New Zealand has done a great deal more than other countries in forest planting) but the preservation of the more valuable forest trees' ${ }^{72}$ His emphasis on indigenous forest management represented a departure from prevailing wisdom. Sir James Wilson grasped what Hutchins was suggesting. He pressed Massey to establish an independent department under a professional forester in 1917, but with little success. In commiserating, Phillips Turner wrote that W.H. Field, a forestry and conservation supporter and MP for Otaki,

tells me that at your interview the other day Mr Massey did not appear to be sympathetically inclined towards the establishment of a forestry department. Well if he will not do this he should be pressed to appoint a qualified expert as director whose authority should be sufficient to ensure the carrying out of what he, the director, considers proper policy and proper treatment for our forests - native and artificial. ${ }^{73}$

Cabinet discussed the issues in early November 1917, and Massey replied to the wartime National Efficiency Board, which was looking to plan for 
postwar economic development, that 'the whole question of reafforestation is being thoroughly taken up by the Lands Department'. ${ }^{74}$ This was, for Hutchins and the proponents of scientific state forests, a backwards step. The National Efficiency Board responded by reminding the Prime Minister that Lands Department 'officers do not fully appreciate the importance of the matter to this Dominion' ${ }^{75}$ Ferguson, the chair of the Efficiency Board, had an unsatisfactory meeting with Massey. He wrote of it to Thomson, exclaiming that "he [Massey] had not the vaguest idea of what forestry meant. So far as I could judge, all he thought forestry consisted of was the planting of trees' ${ }^{76}$ The Cabinet, however, very much shared Massey's position. A joint approach from the National Efficiency Board and the Board of Agriculture produced a further resolution on the need for forest management which was sent to the Prime Minister. Ferguson, appraising Thomson of developments, noted that 'I am informed that Mr. Massey was not very sympathetic to the importation of any more experts' ${ }^{77}$ Massey was doubtless thinking of Hutchins, but could also have been mindful of a succession of experts' reports on forestry in New Zealand stretching back to that of Indian forester Campbell Walker in $1875-1876 .{ }^{78}$ In addition, the National Efficiency Board had over-reached itself by 1918, as John Martin has shown, and Cabinet was moving to trim back its efforts concerning postwar economic directions. ${ }^{79}$

Early in 1918, Wilson wrote to MP David Guthrie, having heard that Guthrie was to replace Massey as Minister of Lands. Presuming Guthrie would also have responsibility for forests, Wilson emphasised that tree planting was only a part of the picture. ${ }^{80}$ Hutchins separately wrote to Wilson of 'well informed' rumours that Sir Francis Bell would take over plantation and state forests as Commissioner of State Forests, and Guthrie, as Minister of Lands, would have responsibility for other forests on Crown lands. ${ }^{81}$ This indeed transpired later in 1918. Hutchins no doubt had his ear to the ground.

Bell became a keen if somewhat unlikely supporter of forestry reform. And it was as well that the pro-forestry lobby found a sympathetic ear in Sir Francis Bell, for Hutchins displayed a refined capacity to annoy and alienate Massey. As G.M. Thomson remarked to Wilson, 'the fact is (strictly confidentially) that Hutchins has sickened Massey with his exaggerated figures, and I don't believe either that practically his proposals would work, ${ }^{82}$ Hutchins' claim in 1919 that timber exports could realise $£ 14$ million, whereas before the war they had amounted to $£ 400,000$, was one instance of his forestry boosterism. ${ }^{83}$ Bell also suffered rebukes from Hutchins. Writing to Wilson he confided, 'I told you I would forget what Hutchins reported to me to be his opinion of my capacity to control trees - but I did not tell 
Massey of it for fear - Massey wants to know if Hutchins objects to Massey as Prime Minister, ${ }^{84}$

Prior to having to confront the forestry question, Massey had been able to adopt a simple dichotomous model of land as being either suitable or unsuitable for settlement. As Minister of Lands, he was able to ensure that land at the boundary was 'correctly' situated, hence his endeavours to have some forest reserves revoked and opened for settlement. There was, however, a considerable imbalance here. Lands officials were well able to make a judgement on the suitability for settlement, but any case for retention of land under forest was made with little knowledge and only a sketchy estimate of the volume of timber carried on the land in question. Massey did recognise that there were limits to settlement, as exemplified by his observation that forest was the best crop the land could produce in some situations. Land unsuited for settlement might be dedicated as state forest and opened to the timber industry, and forest land that had little merchantable timber might be gazetted for soil and water protection, as scenic reserves or national parks. Massey also recognised that the remaining indigenous timber supplies would not satisfy future demands. However, like many of his contemporaries, he tended to see exotic tree planting as the solution to the forest question.

Hutchins brought the viewpoint of a professionally trained colonial forester to New Zealand. Furthermore, he argued that the future of forestry should be based on the long-term management of the indigenous forest on a sustained-yield basis. He claimed that Waipoua kauri forest would produce greater returns than surrounding dairy farms, and he was highly critical of any suggestion that the country should move to an exotic plantation programme for all its future timber supplies.

The forests question was the notable new opportunity that the government had before it in 1918 in terms of natural resource management. Massey played a role in supporting Thomson's initiative for a forest department by appointing the Royal Commission on Forestry in 1913. He took an interest in the fate of Waipoua, and he clashed, not entirely without good reason, with Hutchins. Fortunately, Bell, as Commissioner of State Forests, had become convinced of the value of forestry reform. He oversaw the process whereby forestry was separated from the Lands Department, new legislation introduced and a professional forester appointed. In 1919, Bell orchestrated an amendment to the Forest Act which saw all forest on national endowment lands and other Crown lands designated as Provisional State Forest. This was to have major implications for the future by tipping the historical balance away from settlement as the best use for forests on Crown lands. Its longer term importance was not discussed by Massey in introducing the bill. Indeed, he was keen to reassure members that "where the land is suitable for settlement this Bill will not interfere with it' ${ }^{85}$ Under this 
amendment, however, some 1.8 million acres were immediately gazetted as Provisional State Forest. ${ }^{86}$ New forests legislation was the next step, and this, with Bell in the Legislative Council, was ushered through the House in 1921 by Guthrie as Minister of Lands. Massey's good judgement was in letting Bell get on with this work without interference.

\section{Conclusion}

From the time he entered Parliament in 1894 until 1912, Massey was in opposition. Some major initiatives, including the creation of the first flora and fauna reserves, provision for scenery and historic reserves under the 1892 Land Act, as well as some important debates on native birds, predate his election. From 1894 to 1912, legislation was passed to create four national parks as well as several flora and fauna reserves. The Scenery Preservation Act of 1903 created a country-wide system of what amounted to 769 reserves on 454,127 acres of land by $1925 .{ }^{87}$ But throughout this period, forest reserves could be created and revoked on Crown land, and the amount of Crown forest continued to decline into the 1900s.

Massey's first significant engagement with 'nature' took the form of debating various legislative initiatives for the management of pests and weeds to enable the settler to better make a living off the land. While in opposition and in government, he sought to have some areas of forest reserve revoked so that the lands could be released for settlement. Here, he was supporting conventional development aims that privileged farming over other land uses. Later in his career, he responded to concerns about a coming 'timber famine' by accepting advice that led to the creation of an independent State Forest Service and to new legislation in 1921.

G.M. Thomson, A.K. Newman and W.H. Field were colleagues of Massey who took an active role in forest conservation and nature preservation that equalled that of Liberal MPs such as Harry Ell. Most of the time, Massey was articulating and reiterating a viewpoint that ultimately extended back to the 'sacred' status of freehold land and the 'duty of government' with respect to the settler, whatever topic was being debated in the House. Throughout his time in Parliament, Massey's political philosophy sanctified individual responsibility and rewards in the form of freehold land. He believed in the development of unoccupied land ahead of state intervention inside the agricultural frontier, and favoured local voluntary regulation above national measures. He was not especially antagonistic in principle to some of the goals of nature preservation, particularly if settlement was given first priority, but neither was he particularly energetic in their support. The only exception related to weeds and pests that directly impacted on farming. He was more involved in administrative reform in state forestry, although his own vision, like so many of his colleagues, was largely limited to afforestation. He 
does not appear to have taken up the pervasive but flawed ideas about trees attracting rainfall and improving the climate. Conservation he tended to think of in terms of 'preservation', either for the benefit of future generations, in the case of historic sites and scenic bush, or for future use, in the case of forest reserves. This collapsing of two quite different ends into a single term, 'preservation', ultimately presents problems. Looking at issues that overlapped with the margins of land settlement, Massey clearly did accept a degree of flexibility in the setting of the boundary between settlement and forest as the 'best crop' for the land. Beyond this, he was prepared to accept that scenic areas, particularly on land of limited value for settlement, ought to be preserved rather than destroyed. Some of these layers to his thinking have tended to be neglected.

Massey's attitude towards nature, natural resources and conservation remained remarkably consistent over his 30 years in Parliament. It only really fractured over the issue of scientific state forestry, where a combination of factors was at play. Massey's enthusiasm for revoking forest reserves and draining swamps was consistent with his views about expanding the margins of settlement. He saw forest remnants as having scenic qualities, but wetlands were swamps to be drained for farmland. Both these views had wider currency at the time. Allied to the central position he gave to the freehold and the small farmer was his persistence in drawing to the attention of Liberal politicians the cost of their schemes. Conservation in the form of the preservation of historical and scenic features Massey could support in principle, coming as it did after objectives of land settlement had been largely met. Conservation in the guise of sustained-yield forestry he had more trouble in grasping. Given that it ran counter to the land settlement ethos that was central to Massey's worldview, and came at a time when he faced the demands of the wartime government and was out of the country for significant periods, this was not entirely unexpected. Even so, some blame can be laid at the feet of colonial forester David Hutchins and the nature of his outspoken claims about forestry. Increasingly, these only antagonised Massey, so that it was left to Sir Francis Bell to usher in a professionallystaffed forestry department and new forests legislation in 1921.

In his statements about nature, natural resources and preservation, Massey quite consistently extended the sorts of principles he applied to other areas of society and economy. Thus this paper tends to reinforce the earlier research on Massey's political life, rather than throw up major new insights. Where it does extend the current understanding is by offering a first glance at Massey's views about nature, natural resources and conservation in New Zealand in the late nineteenth and early twentieth centuries. This cluster of topics has generally attracted limited attention from historians, but may be of greater interest to environmental historians, particularly in so far as 
the early twentieth century was the time when concerns over a coming timber famine point to a move away from a belief in superabundant natural resources.

\section{Acknowledgements}

An earlier version of this paper was presented to the 'Massey@ Massey: Reappraising the Life and Times of William Ferguson Massey' conference, Massey University, 1-2 December 2006. The permission of the Parliamentary Library to view the Members Ledgers detailing the borrowing records of MPs is gratefully acknowledged. Professor Eric Pawson generously facilitated access to a copy of J.C. Brown's The Forester.

TABLE 1

Parliamentary Petitions to Resume State Forest Lands 1894 to 1920

\begin{tabular}{cc} 
Year & No. of Motions \\
\hline 1894 & 3 \\
1895 & 5 \\
1896 & 1 \\
1897 & 0 \\
1898 & 3 \\
1899 & 9 \\
1900 & 1 \\
1901 & 1 \\
1902 & 1 \\
1903 & 1 \\
1904 & 3 \\
1905 & 0 \\
1906 & 0 \\
1907 & 3 \\
1908 & 8 \\
1909 & 0 \\
1910 & 6 \\
1911 & 5 \\
1912 & 0 \\
1913 & 9 \\
1914 & 5 \\
1915 & 3 \\
1916 & 2 \\
1917 & 2 \\
1918 & 0 \\
1919 & 2 \\
1920 & 0
\end{tabular}


State Forest Reservations and Revocations (in acres)

\begin{tabular}{crrr} 
Year & Total State Forest & Additions & Revoked \\
\hline 1910 & $2,267,922$ & 8557 & 3857 \\
1911 & $2,300,039$ & 38,870 & 6753 \\
1912 & $2,289,117$ & - & 10,922 \\
1913 & $2,263,663$ & - & 25,454 \\
1914 & $2,239,813$ & - & 23,850 \\
1915 & $2,236,640$ & - & 3773 \\
1916 & $2,248,446$ & 12,600 & 794 \\
1917 & $2,263,321$ & 15,200 & 324 \\
1918 & $2,268,415$ & 8816 & 3724
\end{tabular}

Source: AJHR, C-1, 1910-1918.

1 New Zealand Parliamentary Debates (NZPD), 1895, 91, p.294; W. Buller, A History of New Zealand Birds, 2nd ed., London, 1888.

2 B. Gustafson, 'Massey, William Ferguson 1856-1925', in Dictionary of New Zealand Biography (DNZB), updated 22 June 2007, URL: http://www.dnzb.govt.nz/

3 R. Galbreath, Walter Buller: The Reluctant Conservationist, Wellington, 1989.

4 R. Galbreath, Scholars \& Gentlemen Both. G.M. \& Allan Thomson in New Zealand Science and Education, Wellington, 2002.

5 L.J. Wild, The Life and Times of Sir James Wilson of Bulls, Christchurch, 1953.

6 E. Pawson \& T. Brooking, eds, Environmental Histories of New Zealand, Melbourne, 2002.

7 A broader historical context for the study of weeds in New Zealand is outlined in N. Clayton, 'Weeds, People and Contested Places', Environment and History, 9, 3 (2003), pp. 301-31.

8 D. Thom, Heritage: The Parks of the People, Auckland, 1987; T. Nightingale \& P. Dingwall, Our picturesque heritage: 100 years of scenery preservation in New Zealand, Wellington, 2003.

9 E. Pawson, 'Ell, Henry George 1862-1934', in DNZB, updated 22 June 2007, URL: http://www.dnzb.govt.nz/

10 J.M. Powell, Environmental Management in Australia 1788-1914, Melbourne, 1976; G. Barton, Empire Forestry and the Origins of Environmentalism, Cambridge, 2002.

11 This is one theme of Alfred W. Crosby's influential book Ecological Imperialism: The Biological Expansion of Europe, 900-1900, Cambridge, 2004.

12 D. Hamer, The New Zealand Liberals: The Years of Power, 1891-1912, Auckland, 1988, p.12.

13 T. Brooking, Lands for the People? The Highland Clearances and the Colonization of New Zealand: A Political Biography of John McKenzie, Dunedin, 1996.

14 Appendices to the Journal of the House of Representatives (AJHR), 1930, C-3, p.3. These are estimates and are impressionistic at best, but they represent the most reliable 


\section{The Best Crop the Land Will Ever Grow}

information available prior to the National Forest Inventory 1921-23 carried out by the State Forest Service. The original imperial units are used throughout where they were the original units. One acre is equivalent to 0.4047 hectares.

15 AJHR, 1912, C-1, p.60.

16 In percentage terms, forest cover in the country was closer to $23 \%$ than $16 \%$ in 1923. The discrepancy stems from the fact than the first systematic field-based survey of forest extent did not take place until 1921-23. Earlier estimates also tended to be expressed in terms of volume of merchantable timber rather than forest area.

17 G. Park, "Swamps that might doubtless easily be drained": Swamp drainage and its impact on the indigenous', in Pawson and Brooking, p.151.

18 Massey has never been the subject of a full political biography. Shorter pieces include: Gustafson in DNZB; W.J. Gardner, 'The rise of W. F. Massey, 1891-1912', Political Science (PS), 13, 1 (1961), pp.3-30; and W.J. Gardner, 'W. F. Massey in power, 1912-1925', PS, 13, 2 (1961), pp.3-30.

19 NZPD, 1897, 100, p.608.

20 See, for example, NZPD, 1910, 150, pp.861-77.

21 NZPD, 1905, 134, p.739.

22 The Timber Industry of New Zealand estimated that 70 years supplies remained in 1905. AJHR, 1905, C-6, p.2.

23 Croatians, then subjects of the Austro-Hungarian Empire, were sometimes referred to as 'Jugoslavs' during WWI, although 'Dalmatians' tended to be the more widely-used term in New Zealand until the 1990s. See J. Bassett, 'Colonial Justice: The Treatment of Dalmatians in New Zealand during the First World War', New Zealand Journal of History, 33, 1999, pp.155-79.

24 NZPD, 1899, 110, p.509.

25 For example, see NZPD, 1907, 140, p.427.

26 Massey established a commission to report on which areas should be retained as kauri gum reserves and which should be released to settlement in 1914. AJHR, C-12, 1914.

27 NZPD, 1904, 128, p.400.

28 NZPD, 1903, 124, p.401.

29 Perhaps surprisingly there was no mention of Maori in discussions about swamp drainage until the Tairiei Land Drainage Bill was discussed in 1912, prompted by changes made previously by the Legislative Council. Mr T. Parata (Southern Maori) described the bill as likely to lead to the drainage of lakes designated as Maori 'fishing preserves' (NZPD, 1912, 161, p.920). Massey sought clarification over the proper parliamentary procedures.

30 NZPD, 1924, 203, p.1182.

31 NZPD, 1898, 102, p.182.

32 NZPD, 1899, 102, p.511.

33 Ibid.

34 T. Isern, 'Companions, Stowaways, Imperialists, Invaders, Pests and Weeds in New Zealand', in Pawson and Brooking, pp.233-45.

35 NZPD, 1900, 111, p.462.

36 NZPD, 1900, 111, p.564.

37 AJHR, 1905, C-14.

38 For Massey on Long's noxious weed destroyer, see NZPD, 1909, 148, p.775. On noxious weed amendments, see NZPD, 1904, 128, p.417; 1907, 140, pp.351, 355 and 440; 1909, 144, pp.117 and 530. 


\section{Journal of New Zealand Studies}

39 NZPD, 1908, 140, p.355.

40 NZPD, 1910, 151, p.577.

41 NZPD, 1910, 153, p.216.

42 NZPD, 1913, 163, p.193.

43 NZPD, 1904, 134, p.630. The report was presumably accessed through the Parliamentary Library.

44 NZPD, 1903, 124, p.538.

45 Tongariro National Park was established in 1894, Egmont National Park in 1900, and Sounds (later Fiordland) National Park in 1904. What would become Mt Cook National Park was initially a recreation reserve. It combined the 77,800 acre Tasman Park, reserved in 1887, and the 38,000 acre Mt Cook Glaciers, reserved in 1890. The 150,000 acre Otira and Bealey reserves were established in 1901, and these formed the basis of what became Arthur's Pass National Park in 1929. AJHR, 1903, C-13B.

46 F 11/154, Royal Commission on Forestry, Tongariro National Park Boundaries, Archives New Zealand (ANZ), Wellington.

47 NZPD, 1922, 198, pp.228 and 231.

48 Nightingale \& Dingwall.

49 NZPD, 1903, 126, p.705.

50 NZPD, 1910, 152, p.732.

51 NZPD, 1924, 204, p.104.

52 This did not entirely solve the problem, however, for the Lands Department had responsibility for national parks and allied reserves as well as land development, and these could clash as readily as forestry and scenery preservation.

53 NZPD, 1913, 163, p.617.

54 NZPD, 1913, 163, p.618.

55 NZPD, 1913, 163, p.607.

56 For instance, in 1901, in criticising the ballot system for Crown lands and lands for settlement, Massey remarked that 'people became applicants who have no serious intention whatever of becoming permanent settlers - people who know nothing about land, and do not want to know', NZPD, 1901, 116, p.547.

57 L. Cockayne, 'Report of a Botanical Survey of Waipoua Kauri Forest', AJHR, 1908, C-14.

58 NZPD, 1906, 138, p.376.

59 NZPD, 1912, 160, p.305.

60 A.P. Thomson, 'George Malcolm Thomson and the 1913 Royal Commission on Forestry, Part 1, The political battle', New Zealand Journal of Forestry, 30, 1, 1985, pp.18-27; A.P. Thomson, 'George Malcolm Thomson and the 1913 Royal Commission on Forestry, Part 2, The 1913 Royal Commission', New Zealand Journal of Forestry, 30, 2, 1985, pp.186-93. Thomson borrowed James Brown's The Forester, a two volume edition, from the Parliamentary Library around the time that the forestry commission was being proposed. This book outlined British arboricultural practices, with an emphasis on species selection and tree planting. It was oriented towards estate-level timber production rather than state forestry and the management of indigenous forests in perpetuity, which was what Hutchins was to advocate (Members Ledger, G3, 1912-1914, Parliamentary Library, Wellington).

61 Although Massey made heavy use of the Parliamentary Library, including, alongside lighter reading, such serious tomes as Carlyle's essays and various books on political economy and economics, he did not borrow any of the books dealing with forestry. 
The library's forestry collection included such stock volumes as James Brown's The Forester, numerous books by J. Croumbie Brown on forestry in France and the British Empire, Schlich's Manual of Forestry, as well as annual reports from various Indian State forestry departments. Croumbie Brown's importance has been assessed by Richard Grove in 'Scotland in South Africa: John Croumbie Brown and the Roots of Settler Environmentalism', in T. Griffith and L. Robin, eds, Ecology \& Empire: Environmental Histories of Settler Societies, Melbourne, 1997, pp.139-153. Thus neither Massey, nor his supporters such as Newman and political opponents such as Ell, seem to have availed themselves of the expert material at their fingertips. That said, borrowing a book does not mean it is read or its ideas accepted, some items could have been read in the library rather than being borrowed, and ideas may have been sourced from elsewhere. The borrowing records pose the question of whether New Zealand politicians were perhaps responding to local circumstance to a greater extent when it came to conservation than some accounts suggest, rather than adopting solutions from overseas.

62 NZPD, 1912, 162, p.1365.

63 Land development, particularly swamp draining and forestry, threatened the kahikatea. So valued for providing taint-free butter boxes, the kahikatea grew largely in the swamplands, which were even more valued as potentially rich dairy farmlands.

64 Prime Minister's Address, 26 February 1913, F 11/2, Royal Commission on Forestry, ANZ, Wellington.

65 Ibid.

66 F 11/183, Royal Commission on Forestry, W.F. Massey particulars of forest and other reserves suitable for subdivision and settlement, ANZ, Wellington.

67 NZPD, 1912, 158, p.418.

68 NZPD, 1912, 158, p.499.

69 M. Roche, 'Edward Phillips Turner: The development of a 'Forest Consciousness' in New Zealand 1890s to 1930s', Proceedings of the 6th National Australian Forest History Conference, Augusta, WA 12-17 September, 2004; Wild, 1953.

70 The commission lacked a forester amongst its membership.

71 D.E. Hutchins, 'Scientific Forestry for New Zealand', The New Zealand Journal of Agriculture, 13, 1916, pp.295-317 and 392; D.E. Hutchins, 'The Waipoua Kauri Forest, Its Demarcation and Future Management', New Zealand Journal of Agriculture, 16, 1918, pp.136-141; D.E. Hutchins, New Zealand Forestry, Part 1, Kauri Forests and Forests of the North and Forest Management, Wellington, 1919; M. Roche, 'The Missing Report: Sir David Hutchins and New Zealand Forestry, Part II, Kauri in NZ', The Turnbull Library Record, 38, 2005, pp.35-41.

72 Hutchins to Massey, 16 October 1917, F1 10/3/2, D.E. Hutchins, ANZ, Wellington.

73 Phillips Turner to Wilson, 18 August 1917, MS 2216, no 2, New Zealand Forestry League, Alexander Turnbull Library (ATL).

74 Massey to Ferguson, 6 November 1917, NEB 1/398, Reafforestation in Connection with Returned Soldiers, ANZ, Wellington.

75 Ferguson to Massey 11 December 1917, NEB 1/398, ANZ, Wellington.

76 Ferguson to Thomson 4 November, 1918, NEB 1/398, ANZ, Wellington.

77 Ferguson to Thomson 18 February 1918, NEB 1/398, ANZ, Wellington.

78 L. Brown and A.D. McKinnon, Captain Inches Campbell Walker: New Zealand's First Conservator of Forests, Wellington, 1966.

79 J.E. Martin, 'Blue Print for the future? "National Efficiency" and the First World War', in J. Crawford and I. McGibbon, eds, New Zealand's Great War: New Zealand and the 


\section{Journal of New Zealand Studies}

Allies in the First World War, Auckland, 2006, pp.516-533. I am most grateful to Dr Martin for drawing this tension between Ferguson and Massey to my attention

80 Wilson to Guthrie, 15 February 1918, MS 2216, no 3, New Zealand Forestry League, ATL.

81 Hutchins to Wilson, 26 February 1918, MS 2216, no 3, New Zealand Forestry League, ATL.

82 Thomson to Wilson, 3 January 1918, MS 2216, no 2, New Zealand Forestry League, ATL.

83 D.E. Hutchins, Explanatory Note Regarding Report on Forestry in New Zealand, Wellington, 1919.

84 Bell to Wilson, 15 March 1918, MS 0595, Sir Francis H.D. Bell Letters, ATL.

85 NZPD, 1919, 185, p.735.

86 Compiled from notices in New Zealand Gazette, 1919.

87 AJHR, 1926, C-6, p.4. 